\title{
Altered adipocyte properties in the offspring of protein malnourished rats
}

\author{
BY P. R. SHEPHERD*, N. J. CROWTHER, M. DESAI, C. N. HALES AND S. E. OZANNE $\dagger$ \\ Department of Clinical Biochemistry, University of Cambridge, Addenbrooke's Hospital, Hills Road, \\ Cambridge CB2 2QR
}

(Received 23 August 1996 - Revised 27 December 1996 - Accepted 23 January 1997)

\begin{abstract}
It is becoming well established that poor fetal and early postnatal growth can have long-term effects on adult health, including susceptibility to non-insulin-dependent diabetes mellitus, cardiovascular disease and hypertension. It is suggested that this results from poor nutrition during early life having permanent effects on the structure and metabolism of certain organs and tissues. In the present study we investigated the effect of a low-protein diet during pregnancy and lactation on adipocyte properties and glucose tolerance. Rat dams were fed on a diet containing either 200 (control) or 80 (low protein) g protein/kg during pregnancy and lactation. In addition cross-fostering techniques were employed to enable a separate evaluation of the prenatal and postnatal periods. All offspring were weaned onto a $200 \mathrm{~g}$ protein $/ \mathrm{kg}$ diet at $21 \mathrm{~d}$ of age and then studied at 6 weeks of age. The mothers' protein supply during lactation appeared to be the most critical time window for longterm growth. In contrast, the offspring of mothers fed on a low-protein diet during pregnancy or lactation were significantly more glucose tolerant than controls, suggesting that both time windows can have long-term effects on glucose tolerance. In addition offspring of mothers fed on a lowprotein diet during pregnancy or lactation had significantly smaller adipocytes than controls. However the largest reduction in adipocyte size was observed when there was a low-protein diet during both pregnancy and lactation. The amount of insulin receptor present in adipocyte membranes was increased in the three animal groups that had been exposed to the low-protein diets while levels of the insulin responsive glucose transporter (GLUT 4) were similar in adipocyte membranes from all groups.
\end{abstract}

Maternal diet: Adipocytes: Low-protein diet

A growing number of epidemiological studies suggest that events occurring during fetal growth and development can have long-term effects on adult health. These include studies which have shown a relationship between birth weight and non-insulin-dependent diabetes mellitus (NIDDM) (Hales et al. 1991; Athens et al. 1993; McCance et al. 1994) and cardiovascular disease (Barker et al. 1989). A key factor known to affect birth weight is maternal nutrition. This has been demonstrated in human (Eastman \& Jackson, 1968) and animal studies (Snoeck et al. 1990; Desai et al. 1995). In the latter it has been shown that the offspring of rats fed on a diet containing $80 \mathrm{~g}$ protein $/ \mathrm{kg}$ during pregnancy and lactation are significantly smaller than those from dams fed with $200 \mathrm{~g}$ protein $/ \mathrm{kg}$ diet. These studies have shown that during growth retardation by protein-energy malnutrition there are selective effects on different organs. Some organs, such as the brain are preserved whereas others such as the liver and pancreas are reduced in relation to body weight (Desai et al. 1995).

* Present address: Department of Biochemistry, University College London, London WC1E 6BT.

$\dagger$ For reprints. 
In addition to effects on organ size, poor maternal nutrition has also been shown to have permanent effects on the metabolism of certain organs (Desai et al. 1995). Studies on the offspring of protein-malnourished rats have revealed that these animals have altered levels of expression of hepatic enzymes which play a key role in glucose homeostasis (Desai et al. 1995). These changes are still apparent at 11 months of age after 10 months on a normal diet, suggesting that fetal programming of liver metabolism has occurred. In addition long-term changes in the insulin sensitivity of these livers have been observed (Ozanne et al. 1996b). We have also shown that at 3 months of age offspring of dams fed on low-protein diets have a better glucose tolerance than controls (Hales et al. 1996). However there is a rapid deterioration of glucose tolerance in such offspring, so that at 15 months of age they are significantly less glucose tolerant than controls (Hales et al. 1996). The mechanism by which this occurs is not known. To date no studies have reported the effects of fetal protein malnutrition on adipose tissue. The insulin sensitivity of this tissue is known to be a key determinant of glucose tolerance and adipose tissue is known to be a key site of insulin resistance in NIDDM.

Thus, the aim of the present study was to determine if a low-protein diet during pregnancy and lactation could have a permanent effect on adipocyte cell properties. These results were then related to glucose tolerance.

\section{METHODS}

\section{Materials}

Collagenase (EC 3.4.24.3) was from Worthington (New Jersey, USA) and $\left[{ }^{125} \mathrm{I}\right]$ protein A was from Amersham International (Amersham, Bucks.). GLUT 4 antiserum was supplied by Dr G. Gould, University of Glasgow. Antiserum to the $\beta$-subunit of the insulin receptor was provided by Professor K. Siddle (University of Cambridge). All other chemicals were from Sigma (Poole, Dorset) unless stated otherwise.

\section{Animals}

Virgin female Wistar rats (initial weight $240-260 \mathrm{~g}$ ) used for the study were housed individually and were maintained at $22^{\circ}$ on a $12 \mathrm{~h}$ light-dark cycle. They were mated and day 0 of gestation was taken as the day on which vaginal plugs were expelled. The rats were fed on a diet containing $200 \mathrm{~g}$ protein $/ \mathrm{kg}$ or an isoenergetic diet containing $80 \mathrm{~g}$ protein $/ \mathrm{kg}$ throughout pregnancy and lactation. The composition and source of the diets were described by Snoeck et al. (1990) and are shown in Table 1.

Spontaneous delivery took place on day 22 of pregnancy after which, at $3 \mathrm{~d}$ of age, litters were reduced randomly to eight pups thus ensuring a standard litter size per mother. At this stage half the number of dams from each group continued to nurse their offspring until $21 \mathrm{~d}$ of age. For the remaining dams, cross-fostering techniques were employed, such that the offspring of dams fed on $200 \mathrm{~g}$ protein $/ \mathrm{kg}$ diet were nursed by dams fed on $80 \mathrm{~g}$ protein $/ \mathrm{kg}$ diet (postnatal low protein group) and vice versa (prenatal low protein group) at $21 \mathrm{~d}$ of age all pups were weaned onto a diet containing $200 \mathrm{~g}$ protein $/ \mathrm{kg}$. For simplicity the four groups of offspring are termed 'control', 'low protein', 'prenatal low protein' and 'postnatal low protein'. (The prenatal low protein group has been referred to in previous publications as the 'recuperated' group.) However it is emphasized that only the mothers underwent dietary manipulation. All animals studied were male and 6 weeks of age. 
Table 1. Composition of the control and low-protein diets $(\mathrm{g} / \mathrm{kg})^{*}$

\begin{tabular}{lcc}
\hline \hline & $\begin{array}{c}\text { Control } \\
(200 \mathrm{~g} \text { protein } / \mathrm{kg})\end{array}$ & $\begin{array}{c}\text { Low-protein } \\
(80 \mathrm{~g} \text { protein } / \mathrm{kg})\end{array}$ \\
\hline Mineral and vitamin mixture & 50.5 & 54.5 \\
Casein (880 g protein/kg) & 220.0 & 90.0 \\
DL-Methionine & 2.2 & 0.8 \\
Maize starch & 80.0 & 80.0 \\
Cellulose & 50.0 & 50.0 \\
Soyabean oil & 43.0 & 43.0 \\
Cerelose (glucose) & 551.5 & 681.7 \\
Energy (MJ/kg) & 15.37 & 15.28 \\
\hline \hline
\end{tabular}

* Both diets were obtained from Hoppe Farms BV, Hoge Rijndijk 14, 3440 HD Woerden, The Netherlands.

\section{Glucose tolerance tests}

After an overnight fast, D-glucose ( $1 \mathrm{mg} / \mathrm{g}$ body weight) was injected intraperitoneally in conscious rats. Blood was sampled from the tail vein before injection (time 0 ) and 10, 20, $30,60,120$ and $180 \mathrm{~min}$ after glucose injection.

\section{Blood glucose and plasma insulin determinations}

Blood glucose was measured with a glucose meter (Hemocue, Sheffield, South Yorkshire). Plasma insulin was measured with a Linco radioimmunoassay kit (Biogenesis Ltd, Poole, Dorset) using rat insulin standards.

\section{Fat cell size}

Adipocytes were isolated from epididymal fat pads as described previously (Cushman, 1970) and were then fixed with osmic acid and counted in a Coulter counter (Hirsch \& Gallian, 1968; Cushman \& Salans, 1978) and cell size ( $\mu \mathrm{g} \mathrm{lipid/cell)} \mathrm{was} \mathrm{calculated} \mathrm{as}$ described previously. Briefly, total lipid was extracted from a portion of cells by the method of Dole (1956) and the total lipid per portion was divided by the number of cells in a portion of equal volume, yielding lipid content per cell (Cushman \& Salans, 1978). Fat cell number per fat depot was calculated by dividing the weight $(\mathrm{mg})$ of lipid per fat depot by the weight $(\mu \mathrm{g})$ of lipid per cell.

\section{Western blotting}

Post nuclear adipocyte membranes were prepared as previously described (Shepherd et al. 1993). Membranes $(20 \mu \mathrm{g}$ protein) were subjected to SDS-PAGE on a $100 \mathrm{~g} / 1$ acrylamide gel and transferred electrophoretically onto polyvinyldifluoride. The filter was then blocked in $50 \mathrm{~mm}$-Tris- $\mathrm{HCl}$ (pH 7.4) containing $150 \mathrm{mM}-\mathrm{NaCl}$ (TBS), $1 \mathrm{ml}$ Tween $20 / 1$ and $10 \mathrm{~g}$ non-fat milk powder $/ 1$ and then incubated for $3 \mathrm{~h}$ at room temperature in the same solution containing either anti-GLUT 4 antiserum or anti-insulin-receptor antiserum. Filters were subsequently washed and incubated with [ ${ }^{125}$ I]protein-A. Radioactive bands were detected and quantified on a BAS-2000 phosphoimager (Fujix, Kanagawa, Japan). 


\section{Statistical analyses}

All statistical calculations were carried out using Statworks statistical software (Cricket Graph III, version 1.0; Computer Associates, New York 11788, NY, USA). For all data sets it was first determined that the data were normally distributed and, where comparisons were to be made, that there was no significant difference in the variances of the two groups. These conditions were met in all cases and the significance of any difference between groups was examined by Student's $t$ test and ANOVA. Results in all cases are given as means with their standard errors, together with the absolute probability $(P)$ value where appropriate.

\section{RESULTS}

\section{Animal growth}

The growth curves for the four groups of animals from birth to 6 weeks of age are shown in Fig. 1. The offspring of rats fed on a low-protein diet during pregnancy weighed significantly less at $3 \mathrm{~d}$ of age than offspring from control dams (5.05 (SE 0.31) g compared with 6.92 (SE 0.66 ) g respectively, $P<0.01$ ). At 6 weeks of age, when glucose tolerance tests were performed and adipocytes analysed, the body weight of the low protein animals was $26 \%$ less than that of controls (Fig. 1). Similar observations were made for the postnatal low protein group, growth being signficantly $(P<0.001)$ retarded compared with controls (Fig. 1). In contrast, the prenatal low protein animals showed rapid catch-up growth so that at the time of adipocyte analysis their body weights were not significantly different from controls (Fig. 1).

\section{Glucose tolerance tests}

Six-week-old low protein animals had significantly lower fasting plasma glucose concentrations than controls (Table 2). In addition fasting plasma insulin concentrations were significantly $(P<0.02)$ lower in the low protein animals $(122$ (SE 24) pmol/l) compared with controls (264 (SE 53) pmol/l). After administration of glucose, the normal rise in blood glucose was significantly reduced in low protein animals at the 10,20 and 30 min time points (Table 2). However, there were no differences in plasma insulin concentrations (323 (SE 65) pmol/l in controls and 304 (SE 39) pmol/l in the low-protein group, $30 \mathrm{~min}$ after administration of glucose).

Both crossover groups had similar fasting plasma glucose concentrations compared with controls (Table 2). However both crossover groups had significantly lower fasting plasma insulin concentrations than controls (106 (SE 26) pmol/l, $P<0.03$ for the postnatal low protein group and 75 (SE 13), $P<0.04$ for the prenatal low protein group, both compared with controls). In addition, after administration of glucose, there was a much smaller rise in blood glucose compared with controls. At most time points both crossover groups had significantly lower blood glucose concentrations than controls and throughout the glucose tolerance test (with the exception of the fasting sample) the crossover group blood glucose concentrations were not significantly different from those of the low protein group (Table 2).

\section{Fat cell size and numbers}

At 6 weeks of age the low protein offspring had significantly $(P<0.001)$ smaller fat pads than controls (1.69 (SE 0.06) $\mathrm{g}$ and 0.83 (SE 0.04) $\mathrm{g}$ in controls and low protein groups, respectively; Table 3 ). This was also reflected by a reduction in fat cell number per pad 


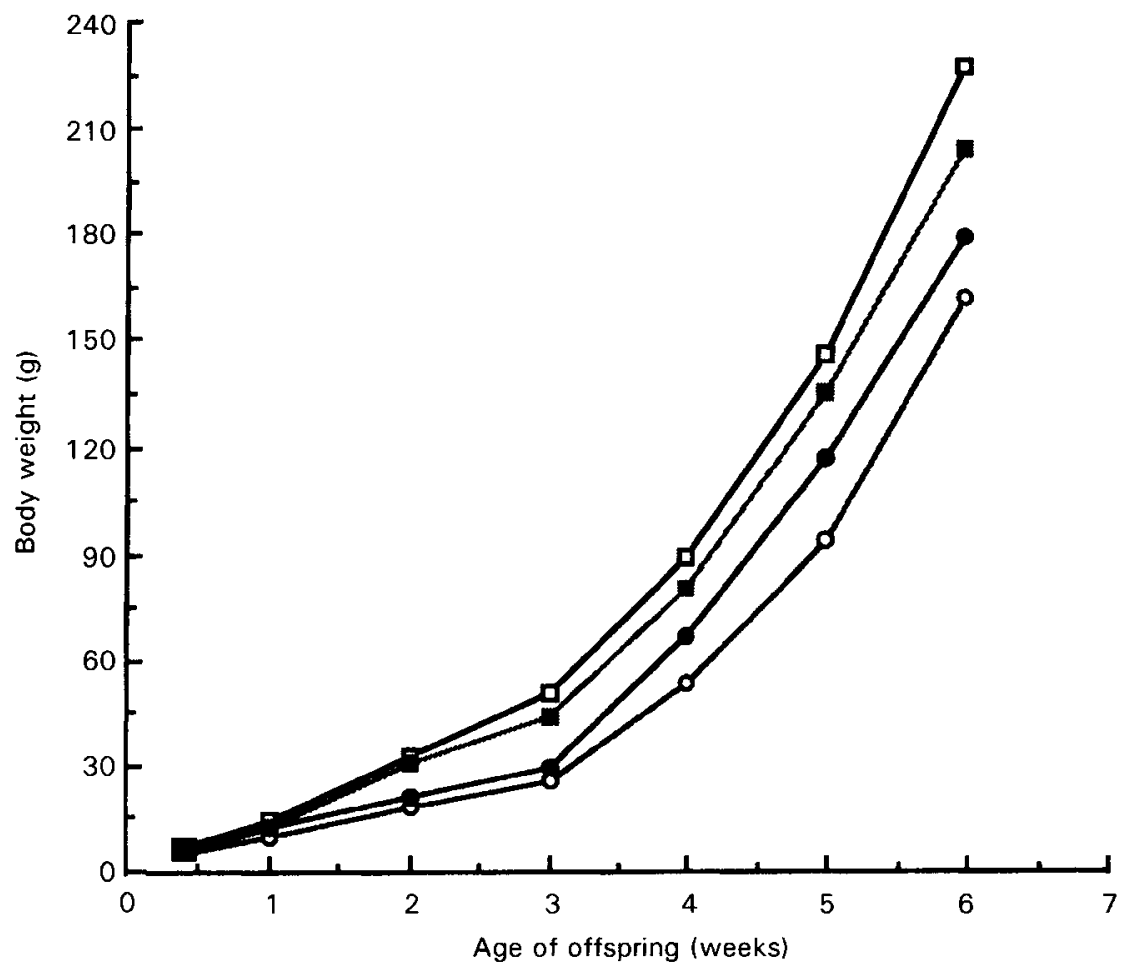

Fig. 1. Body weights of offspring of dams fed on diets containing $200 \mathrm{~g}$ protein $/ \mathrm{kg}$ (control, $\square$ ) or $80 \mathrm{~g}$ protein $/ \mathrm{kg}$ (low protein, $O$ ) throughout pregnancy and lactation, and offspring cross-fostered with dams fed on these diets (postnatal low protein, ; prenatal low protein, $\square$ ). Values are means for sixteen male animals per group (from eight litters per group); standard errors were small and have been obscured by the symbols at each point.

Table 2. The results of glucose tolerance tests (plasma glucose, mmol/l) in the offspring of rats fed on diets containing $200 \mathrm{~g}$ protein $/ \mathrm{kg}$ (control) or $80 \mathrm{~g}$ protein $/ \mathrm{kg}$ (low protein) throughout pregnancy and lactation, and offspring cross-fostered with dams fed on these diets (postnatal low protein and prenatal low protein) +

(Mean values with their standard errors for sixteen male animals per group from eight litters)

\begin{tabular}{|c|c|c|c|c|c|c|c|c|}
\hline \multirow[b]{2}{*}{ Time (min) } & \multicolumn{2}{|c|}{ Control } & \multicolumn{2}{|c|}{ Low protein } & \multicolumn{2}{|c|}{$\begin{array}{l}\text { Postnatal } \\
\text { low protein }\end{array}$} & \multicolumn{2}{|c|}{$\begin{array}{l}\text { Prenatal } \\
\text { low protein }\end{array}$} \\
\hline & Mean & $\mathrm{SE}$ & Mean & $\mathrm{SE}$ & Mean & SE & Mean & $\mathrm{SE}$ \\
\hline 0 & $4 \cdot 0$ & 0.1 & $3 \cdot 6^{* *}$ & 0.1 & $4.1 \dagger$ & 0.3 & $4.4 \dagger$ & 0.2 \\
\hline 10 & $6 \cdot 8$ & 0.1 & $6 \cdot 2 * *$ & 0.2 & $6 \cdot 0^{* *}$ & 0.2 & 6.5 & 0.3 \\
\hline 20 & 7.5 & 0.2 & $6 \cdot 8 * *$ & 0.3 & $6 \cdot 3 * * *$ & 0.2 & $6.8^{*}$ & 0.3 \\
\hline 30 & 7.7 & 0.1 & $7 \cdot 1 * *$ & 0.2 & $6 \cdot 6^{* * *}$ & 0.3 & $7 \cdot 1 * *$ & 0.3 \\
\hline 60 & 6.7 & $0 \cdot 1$ & 6.6 & 0.2 & $5 \cdot 9 * *$ & 0.3 & $6 \cdot 2^{*}$ & 0.2 \\
\hline 90 & 6.0 & 0.1 & 6.0 & 0.1 & $5.6^{*}$ & 0.2 & 5.8 & 0.15 \\
\hline 180 & 5.5 & 0.1 & 5.2 & 0.1 & $5 \cdot 1 *$ & 0.2 & $5 \cdot 1^{*}$ & 0.1 \\
\hline
\end{tabular}

Mean values were significantly different from those for controls: $* P<0.05, * * P<0.01, * * * P<0.001$.

$\dagger$ Mean values were significantly different from those for the low protein group, $P<0 \cdot 05$.

$\$$ For details of diets and procedures, see Table 1 and pp. 122-123. 
$(P<0.05)$. However the low protein group's adipocytes were significantly smaller $(P<0.001)$ than those of controls $(52.2$ (SE 1.4) $\mu \mathrm{m}$ compared with $71.6(\mathrm{SE} 0.9) \mu \mathrm{m})$ thus the difference in fat cell numbers was not as great as the difference in fat-pad size.

At the same age, both crossover groups also had significantly smaller fat pads than controls $(P<0.03$ for control $v$. prenatal low protein, $P<0.001$ for control $v$. postnatal low protein). However the fat pads of the prenatal low protein animals were much larger than those of the postnatal low protein $(P<0.001)$ and low protein $(P<0.001)$ animals. In addition both crossover groups had significantly $(P<0.001)$ smaller adipocytes than control animals (Table 3). However these prenatal and postnatal low protein adipocytes were significantly $(P<0 \cdot 01)$ larger than adipocytes from low protein animals.

\section{Levels of GLUT 4 and insulin receptor in adipocyte membranes}

The levels of GLUT 4 were not significantly different in adipocyte membranes of any of the animal groups (Table 4). However, the levels of insulin receptor were approximately 2fold higher in adipocytes from low protein and prenatal low protein groups compared with controls $(P<0.01 v$. control, Table 4). Insulin receptor levels were also slightly elevated in the postnatal low protein group, however this did not reach statistical significance in the number of animals studied $(P=0.06)$.

\section{DISCUSSION}

The present study was designed to address the hypothesis that fat cell size and number in adulthood can be programmed by events which occur during fetal and early postnatal life. We focused on the long-term effects of poor nutrition using a rat model where rat dams are fed on either a low $(80 \mathrm{~g} / \mathrm{kg})$ protein or a control $(200 \mathrm{~g} / \mathrm{kg})$ diet during pregnancy and lactation. The relative importance of pregnancy and lactation individually was addressed by including two crossover groups in the study. We have shown previously using the same animal model that offspring of mothers fed on a low-protein diet have permanent changes in liver enzyme activities. (Desai et al. 1995) and plasma levels of cholesterol, HDL and triacylglycerols (Lucas et al. 1996). The results of the current study reveal that there are

Table 3. Fat pad and adipocyte cell size in the offspring of dams fed on diets containing $200 \mathrm{~g}$ protein $/ \mathrm{kg}$ (control) or $80 \mathrm{~g}$ protein $/ \mathrm{kg}$ (low protein) throughout pregnancy and lactation, and offspring cross-fostered with dams fed on these diets (postnatal low protein and prenatal low protein $) \dagger$

(Mean values with their standard errors for sixteen animals per group from eight litters)

\begin{tabular}{|c|c|c|c|c|c|c|c|c|}
\hline & \multicolumn{2}{|c|}{ Control } & \multicolumn{2}{|c|}{ Low protein } & \multicolumn{2}{|c|}{$\begin{array}{l}\text { Postnatal low } \\
\text { protein }\end{array}$} & \multicolumn{2}{|c|}{$\begin{array}{c}\text { Prenatal low } \\
\text { protein }\end{array}$} \\
\hline & Mean & $\mathrm{SE}$ & Mean & $\mathrm{SE}$ & Mean & $\mathbf{S E}$ & Mean & SE \\
\hline Fat pad wt (g) & 1.7 & $0 \cdot 1$ & $0.8 * * *$ & 0.1 & $1 \cdot 0^{* * *}$ & 0.1 & $1.5^{*}$ & 0.1 \\
\hline $\begin{array}{l}\text { Adipocyte dia- } \\
\text { meter }(\mu \mathrm{m})\end{array}$ & $71 \cdot 6$ & 0.9 & $52 \cdot 2 * * *$ & 1.4 & $61.5^{* * *}$ & 0.6 & $64.7 * * *$ & 0.9 \\
\hline $\begin{array}{l}\text { Adipocytes/pad } \\
\left(\text { cells } \times 10^{6}\right)\end{array}$ & $18 \cdot 7$ & 1.2 & $15 \cdot 6^{* * * *}$ & $1 \cdot 3$ & ND & & ND & \\
\hline
\end{tabular}

ND, not determined

Mean values were significantly different from those for the control group: $* P<0.03, * * * P<0.001$.

$\dagger$ For details of diets and procedures, see Table 1 and pp. 122-123. 
Table 4. GLUT 4 and insulin receptor levels (arbitrary phosphoimager units) in adipocyte membranes in the offspring of dams fed on diets containing $200 \mathrm{~g}$ protein/ $\mathrm{kg}$ (control) or $80 \mathrm{~g}$ protein/kg (low protein) throughout pregnancy and lactation, and offspring cross-fostered with dams fed on these diets (postnatal low protein and prenatal low protein) $\dagger$

(Mean values with their standard errors)

\begin{tabular}{|c|c|c|c|c|c|c|c|c|}
\hline \multirow[b]{2}{*}{ Antibody } & \multicolumn{2}{|c|}{ Control ( $n$ 8) } & \multicolumn{2}{|c|}{ Low protein $(n 6)$} & \multicolumn{2}{|c|}{$\begin{array}{c}\text { Postnatal } \\
\text { low protein }(n 6)\end{array}$} & \multicolumn{2}{|c|}{$\begin{array}{l}\text { Prenatal low protein } \\
\qquad(n 6)\end{array}$} \\
\hline & Mean & SE & Mean & SE & Mean & SE & Mean & $\mathrm{SE}$ \\
\hline GLUT 4 & 61.6 & $3 \cdot 1$ & 57.6 & $2 \cdot 2$ & $53 \cdot 1$ & $4 \cdot 1$ & $68 \cdot 1$ & $\overline{2.9}$ \\
\hline Insulin receptor & $9 \cdot 0$ & 1.4 & $17 \cdot 6^{* *}$ & 1.8 & $14 \cdot 3$ & $2 \cdot 2$ & $17.8 * *$ & 1.8 \\
\hline
\end{tabular}

** Mean values were significantly different from those for the control, $P<0.01$.

$\dagger$ For details of diets and procedures, see Table 1 and pp. 122-123.

different time windows of susceptibility for early programming of body growth, glucose tolerance and adipocyte properties.

As observed previously (Desai et al. 1996) differences in maternal protein supply during lactation have a much greater effect than protein supply during pregnancy on later body weight. The offspring of the low-protein-fed dams weighed significantly less than controls at $3 \mathrm{~d}$ of age suggesting that maternal protein restriction causes growth retardation of the fetus. However at 6 weeks of age there were no differences in body weights of the control and prenatal low protein groups suggesting that a plentiful supply of maternal protein during lactation allows a rapid catch-up growth of offspring which were growth retarded in utero. In contrast poor nutrition during lactation causes growth retardation which is still apparent 3 weeks after weaning onto a normal diet.

Changes in glucose tolerance however appeared to be affected equally by fetal and early postnatal poor nutrition. Both crossover groups and the low protein group had significantly better glucose tolerances than control animals at 6 weeks of age. The glucose tolerances of both crossover groups were similar to that of low protein offspring. This suggests that both pregnancy and lactation are critical time windows in the determination of young adult glucose tolerance. The apparent improvement in glucose tolerance observed in the low protein offspring appears to be due at least in part to increased insulin sensitivity. This is demonstrated by the observation that the low protein animals had lower fasting plasma insulin concentrations coupled with lower fasting plasma glucose concentrations than controls.

A low-protein diet during either pregnancy or lactation was observed to have longterm effects on fat-pad size. Both crossover groups had significantly smaller fat pads than controls. However, like body weight, the reduction in fat-pad size was much greater in the postnatal low-protein animals suggesting that fat-pad size is maintained as a proportion of body weight. In contrast adipocyte size was dramatically reduced in both crossover groups to a similar extent. Thus nutrition during pregnancy and lactation plays a critical role in the determination of adipocyte size in young adulthood. Previous studies have shown that adipocyte size can be altered by dietary manipulation in adult rats (Faust et al. 1978). However this effect was reported as being transient, adipocyte cell size returning to normal after reintroduction of normal laboratory chow. In the present study the effect of poor early nutrition was not a transient observation. The difference in adipocyte size persisted after a substantial time on a normal diet suggesting that programming of fat cell size had occurred during fetal and early postnatal life. Adipocyte size could be a key factor that contributes to 
the observed increased insulin sensitivity. It has been reported previously that small adipocytes are more insulin sensitive than large ones (Crandell et al. 1983).

The molecular basis for the association of differences in adipocyte size with changes in whole-body glucose utilization is not fully understood. Alterations at the level of adipocyte insulin receptor have been found in some insulin-resistant states and differences generally correlate with the insulin responsiveness of the adipocyte. Insulin receptor numbers are known to decrease with increasing age and to be reduced in enlarged adipocytes from obese human subjects and obese animal models (reviewed by Haring, 1991). Increased insulin receptor levels have been reported in the pre-obese fa/fa Zucker rat where adipocytes display increased insulin responsiveness (Debant et al. 1987). In the current study, levels of insulin receptor were elevated 2-fold in adipocyte membranes from low protein and prenatal low protein animals. We have recently reported a similar increase in insulin receptors in liver (Ozanne et al. 1996a) and skeletal muscle (Ozanne et al. 1996b) of low protein offspring. There was a smaller elevation of insulin receptors in adipocytes from the postnatal low protein animals suggesting that a low-protein diet during the fetal period has a greater effect on insulin receptor expression than during the lactation period. These elevations in insulin receptors may contribute to the improved glucose tolerance in all three low protein groups.

The level of GLUT 4 transporter expression is also thought to contribute to the ability of insulin to stimulate glucose transport into adipocytes. It is known that increasing levels of GLUT 4 in adipocytes in transgenic mice leads to increases in adipocyte glucose metabolism as well as whole-body insulin sensitivity (Shepherd et al. 1993; Tozzo et al. 1995). Conversely the decreased insulin responsiveness of adipocytes associated with ageing and the decreased responsiveness associated with the enlarged adipocytes from obese insulin-resistant models and obese insulin-resistant human subjects is associated with decreases in the levels of GLUT 4 (reviewed by Shepherd \& Kahn, 1994). However in the present study we saw no changes in expression of GLUT 4. Therefore alterations in GLUT 4 levels in adipocytes do not explain the observed differences in insulin sensitivity.

In conclusion we have demonstrated that the relatively short time window of pregnancy and lactation can have long-term effets on adipocyte properties and insulin sensitivity in offspring. We have shown previously that low protein offspring undergo a rapid deterioration in glucose tolerance in late adult life (Hales et al. 1996). It is currently unclear if this is paralleled by changes in adipocyte size and/or metabolism or expression levels of GLUT 4 or insulin receptors. However it is hoped that by identifying critical time windows in early life that contribute to the development of adult diseases, rational nutrition intervention programmes can be designed.

We thank D. Hutt, A. Flack, A. Wayman and L. Smith of the Dunn Nutritional Laboratory Animal Unit for their invaluable assistance. We are also grateful to Dr Tim Aitman of the Hammersmith Hospital for his help with the fat cell size measurements. This work was supported by the Medical Research Council, the Parthenon Trust and the British Diabetic Association.

\section{REFERENCES}

Athens, M., Valdez, R. \& Stern, M. (1993). Effect of birthweight on future development of 'syndrome X' in adult life. Diabetes 42, Suppl. 1, 61A Abstr.

Barker, D. J. P., Winter, P. D., Osmond, C., Margetts, B \& Simmonds, S. J. (1989). Weight in infancy and death from ischaemic heart disease. Lancet ii, 577-580. 
Crandall, D. L., Fried, S. K., Francendese, A. A., Nickel, M. \& DiGirolamo, M. (1983). Lactate release from iolated rat adipocytes: influence of cell size, glucose concentration, insulin and epinephrine. Hormone and Metabolic Research 15, 326-329.

Cushman, S. W. (1970). Structure-function relationships in the adipose cell. 1. Ultrastructure of the isolated adipose cell. Journal of Cell Biology 46, 326-341.

Cushman, S. W. \& Salans, L. B. (1978). Determination of adipose cell size and number in suspensions of isolated rat and human adipose cells. Journal of Lipid Research 19, 269-273.

Debant, A., Guerre-Millo, M., Le-Marchand-Brustel, Y., Freychett, P., Lavau, M. \& Van Obberghen, E. (1987). Insulin receptor tyrosine kinase is hyperresponsive in adipocytes of young obese Zucker rats. American Journal of Physiology 252, E273-E278.

Desai, M., Crowther, N. J., Lucas, A. \& Hales, C. N. (1996). Organ-selective growth in the offspring of protein restricted mothers. British Journal of Nutrition 76, 591-603.

Desai, M., Crowther, N. J., Ozanne, S. E., Lucas, A. \& Hales, C. N. (1995). Adult glucose and lipid metabolism may be programmed during fetal life. Biochemical Society Transactions 23, 331-335.

Dole, V. P. (1956). A relation between non-esterified fatty acids in plasma and the metabolism of glucose. Journal of Clinical Investigation 35, 150-155.

Eastman, N. J. \& Jackson, E. (1968). Weight relationship in pregnancy 1 . The bearing of maternal weight gain and pre-pregnancy weight on birthweight in full term pregnancies. Obstetric and Gynecological Surveys 23, 1003-1024.

Faust, I. M., Johnson, P. R., Stern, J. S. \& Hirsch, J. (1978). Diet-induced adipocyte number increase in adult rats: a new model of obesity. American Journal of Physiology 235, E279-E285.

Hales, C. N., Barker D. J. P., Clark P. M. S., Cox L. J., Fall C. \& Winter, P. D. (1991). Fetal and infant growth and impaired glucose tolerance at age 64 years. British Medical Journal 303, 1019-1022.

Hales, C. N., Desai, M., Ozanne, S. E. \& Crowther, N. J. (1996). Fishing in the stream of diabetes: from measuring insulin to the control of fetal organogenesis. Biochemical Society Transactions 24, 341-350.

Haring, E. U. (1991). The insulin receptor: signalling mechanisms and contribution to pathogenic insulin resistance. Diabetologia 34, 848-857.

Hirsch, J. \& Gallian, E. (1968). Methods for the determination of adipose cell size in man and mammals. Journal of Lipid Research 9, 110-119.

Lucas, A., Baker, B. A., Desai, M. \& Hales, C. N. (1996). Nutrition in pregnant or lactating rats programs lipid metabolism in the offspring. British Journal of Nutrition 76, 605-612.

McCance, D. R., Pettitt, D. J., Hanson, R. L., Jacobsson, L. T. H., Knowle, W. C. \& Bennet, P. H. (1994). Birthweight and non-insulin-dependent diabetes: 'thrifty genotype', 'thrifty phenotype', or 'surviving small baby genotype'. British Medical Journal 38, 942-945.

Ozanne, S. E., Smith, G. D., Tikerpae, J. \& Hales, C. N. (1996a). Altered regulation of hepatic glucose output in the male offspring of protein malnourished rat dams. American Journal of Physiology 270, E559-E564.

Ozanne, S. E., Wang, C. L., Coleman, N. \& Smith, G. D. (1996b). Altered insulin sensitivity in the male offspring of protein malnourished rats. American Journal of Physiology 271, E1 128-E1134.

Shepherd, P. R., Gnudi, L., Tozzo, E., Yang, H., Leach, F. \& Kahn, B. B. (1993). Adipose cell hyperplasia and enhanced glucose disposal in transgenic mice overexpressing GLUT 4 selectively in adipose tissue. Journal of Biological Chemistry 268, 22243-22246.

Shepherd, P. R. \& Kahn, B. B. (1994). Expression of the GLUT 4 glucose transporter in diabetes. In Molecular Biology of Diabetes, pp. 529-546 [B. Draznin and D. LeRoith, editors]. Totowa, NJ: Humana Press.

Snoeck, I., Remacle, C., Reusens, B. \& Hoet, J.-J. (1990). Effect of a low protein diet during pregnancy on the fetal rat endocrine pancreas. Biology of the Neonate 57, 107-118.

Tozzo, E., Shepherd, P. R., Gnudi, L. \& Kahn, B. B. (1995). Transgenic GLUT 4 overexpression in fat enhances glucose metabolism: preferential effect on fatty acid synthesis. American Joumal of Physiology 268 , E956-E964. 